\title{
AJANKOHTAISTA
}

\section{Tutkimushanke ikääntyvien oikeudensaantimahdollisuuksista käynnissä}

\section{Hankkeen käynnistyminen}

Helsingin yliopiston, Itä-Suomen yliopiston, Tampereen yliopiston ja Ihmisoikeuskeskuksen yhteistyönä käynnistettiin loppuvuodesta 2020 ikääntyvien $(65+)$ oikeudensaantimahdollisuuksiin keskittyvä tutkimusprojekti. Kyse on yhteiskunnallisen oikeustutkimuksen (Law \& Society, Socio-Legal Studies) alaan kuuluvasta empiirisestä tutkimushankkeesta, jossa mukana on oikeustieteen, sosiaalipolitiikan, sosiologian ja gerontologisen sosiaalityön tutkijoita. Hanketta johtavat yhteiskunnallisen oikeustutkimuksen professori Kaijus Ervasti ja vanhuusoikeuden professori Anna Mäki-PetäjäLeinonen.

Ikääntyvän väestön määrä lisääntyy niin Suomessa kuin muissakin länsimaissa. Samalla lisääntyvät ikääntyvien oikeudelliset ongelmat. Ne voivat liittyä esimerkiksi asumiseen, perheeseen, tavaroiden ja palveluiden hankintaan, kaltoinkohteluun sekä erilaisiin sosiaali- ja terveyspalveluihin. Ei ole tietoa, kuinka laajasti ikääntyvillä on erilaisia ongelmia ja millaisiin keinoihin he ovat turvautuneet niiden ratkaisemiseksi.

Ensi vaiheessa joulukuusta 2020 helmikuun 2021 loppuun ikääntyviltä ja heidän läheisiltään pyydettiin kertomuksia oikeusongelmista ja niiden ratkaisemisesta lehti-ilmoituksilla (esimerkiksi Helsingin Sanomat, Aamulehti, Kaleva, Huvustadsbladet ja ET) sekä sosiaalisen median ja kansalaisjärjestöjen kautta. Ikääntyneitä tai heidän läheisiään pyydettiin kirjoittamaan vapaamuotoinen teksti, jossa he kertovat koetuista oikeudellisista ongelmista, minkä tahon puoleen asiassa on käännytty ja ovatko ongelmat tulleet ratkaistuiksi. Pyyntöä jaettiin suomeksi, ruotsiksi, kolmella saamen kielellä sekä romaniksi. Kertomuksia pyydettiin lähettämään helmikuun 2021 loppuun mennessä.

\section{Oikeudensaantimahdollisuudet}

Tutkimushankkeemme liittyy oikeudensaantimahdollisuuksien tutkimusperinteeseen (Access to Justice), jonka mukaan oikeudellisissa tutkimuksissa ei pitäisi keskittyä pelkästään muodollisiin oikeuksiin vaan siihen, toteutuvatko lain takaamat oikeudet käytännössä. Tällöin pitäisi hyödyntää yhteiskuntatieteellisiä, ihmistieteellisiä ja taloustieteellisiä analyyseja. (Cappelletti \& Garth 1981; Ervasti 2011.) Perinteisinä esteinä oikeuden saamiselle on pidetty taloudellisia (esimerkiksi asiantuntijaavun käyttö), organisatorisia (esimerkiksi pääsy sosiaalisiin oikeuksiin) ja menettelyllisiä (esimerkiksi pääsy tuomioistuimeen) esteitä. Ikääntyvä väestö ja muut haavoittuvat ryhmät törmäävät myös moniin muihin esteisiin oikeuden saamisessa. Ne voivat olla esimerkiksi sosiaalisia, kulttuurisia, teknologisia sekä kommunikaatioon ja henkilöön liittyviä. (Access to Justice and Legal Needs 2004.)

Oikeuksien toteutuminen edellyttää tietoa oikeuksista ja niiden toteuttamisesta. Lisäksi oikeudensaantimahdollisuudet edellyttävät yleensä mahdollisuutta turvautua oikeudelli- 


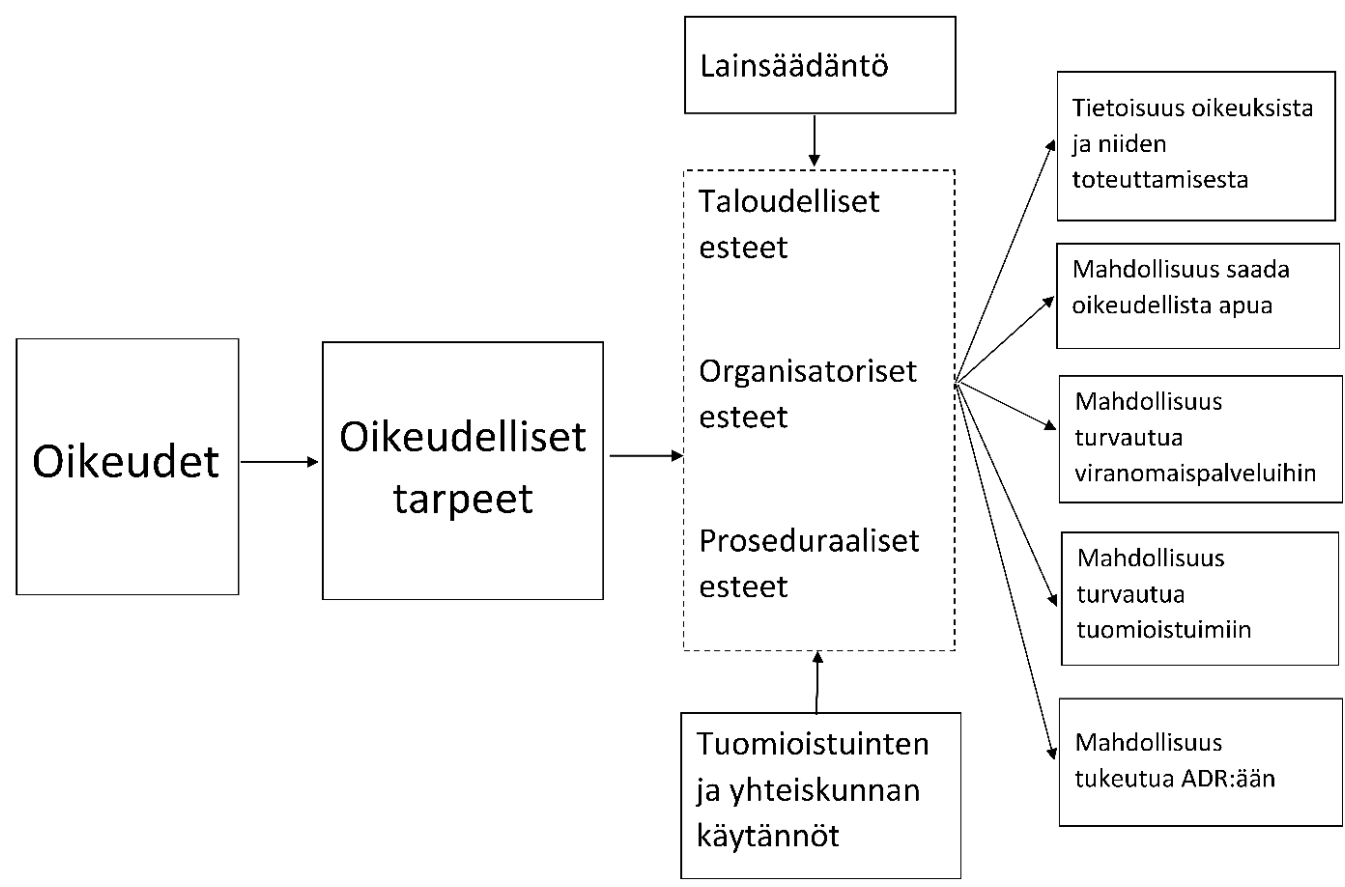

Kuvio 1. Oikeudensaantimahdollisuudet ja esteet.

seen apuun sekä tarvittaessa oikeussuojakoneistoon eli viranomaisiin, tuomioistuimiin ja vaihtoehtoisiin konfliktinratkaisuelimiin (ADR eli Alternative Dispute Resolution). (Ks. Cappelletti 1993; Ervasti \& Nylund 2014.) Kuviossa 1 on esitetty tiivistetysti, mistä oikeudensaantimahdollisuuksissa on kyse.

Oikeudensaantimahdollisuuksia on tutkittu länsimaissa jonkin verran, mutta ikääntyvien ihmisten oikeudensaantimahdollisuuksista on tutkimustietoa vain rajatusti. Aihetta ei ole myöskään tutkittu oikeudellisesta näkökulmasta pyytämällä ikääntyviltä ihmisiltä sitä koskevia kirjoituksia. Aiemmin Suomessa on selvitetty vanhusten kohtaamia haasteita digipalveluissa niin sanotun kansalaistutkimuksen keinoin keräämällä kertomuksia ikääntyneiltä SOSTEn julkaisemassa selvityksessä Ihan piballa? (Koskiaho \& Saarinen 2019). Aineiston keskittyessä ikäihmisten kokemuksiin tutkimus liittyy myös koetun oikeudenmukaisuuden tutkimusperinteeseen.

\section{Aineisto}

Helmikuun 2021 loppuun mennessä sähköpostitse ja kirjeitse saapui yhteensä 324 kertomusta. Kokonaisaineisto on laadulliseksi aineistoksi sangen suuri. Aineistossa esiintyy monenlaisia ongelmia esimerkiksi sosiaali- ja terveyspalveluissa, sosiaalietuuksissa, asumisessa, verotuksessa sekä perhe- ja perintöoikeudellisissa asioissa. Lisäksi ikääntyvät ja heidän läheisensä raportoivat kaltoinkohtelusta.

Hanke vastaanotti myös noin 120 puhelua. Soittajat kysyivät neuvoa kertomusten laatimiseen ja ilmaisivat tyytyväisyytensä siihen, että vanhusten ongelmia tutkitaan. Monilla tuntui olevan tarvetta kertoa kokemistaan vääryyksistä jollekin ulkopuoliselle. Soittajat kuvasivat muun muassa erilaisissa hallinto- ja terveyspalveluissa kohtaamiaan epäoikeudenmukaisuuden kokemuksia. Monet kokivat, että ikääntyneitä pidetään toisen luokan kansalaisina. 
Yhteydenottajina olivat niin ongelmia kokeneet ikäihmiset itse kuin heidän puolisonsa tai läheisensä. Selkeästi erottuvia ryhmiä ovat omaishoitajat ja vanhempiensa oikeuksista huolestuneet aikuiset lapset, jotka kertoivat vanhempiensa tarinan. Osallistujien laaja kirjo mahdollistaa tutkimuksen tekemisen näiden eri ryhmien näkökulmasta.

Tutkimusaineisto järjestettiin ja koodattiin Atlas.ti-ohjelmalla. Tapauksista on myös kvantifioitu keskeisiä taustamuuttujia kokonaiskuvan luomiseksi. Kertomuksista huokuu vahva kokemuksellisuus, ja yksi mahdollisuus on tarkastella aineistoa koetun yhteiskunnallisen oikeudenmukaisuuden näkökulmasta. Seuraavassa vaiheessa aineisto analysoidaan sisällönanalyysilla. Syksyllä 2021 tutkimusta on tarkoitus syventää haastatteluilla.

Tutkimuksessa keskitytään ensinnäkin siihen, millaisia oikeusongelmia ikääntyvät ihmiset ovat kohdanneet. Aineistossa nousee esiin monenlaisia ongelmia, mutta erityisesti korostuvat sosiaali- ja terveyspalvelut sekä asuminen. Lisäksi selvitetään, mistä ikäihmiset ovat hakeneet apua ja kokevatko he saaneensa apua ongelmiinsa. Aineistoa käsiteltäessä on merkitty ylös käytetyt oikeusasteet ja yhteydenotot eri viranomaisiin tai palvelun tarjoajiin oman asian hoidossa. Apua voidaan hakea esimerkiksi ammattiliitoista, erilaisista järjestöistä, kunnalta tai läheisiltä.

Kertomuksista analysoidaan myös, millaisten tekijöiden henkilöt kokevat olevan ongel-

\section{Kirjallisuus}

Access to justice and legal needs: the legal needs of older people in NSW. Law and Justice Foundation of New South Wales, 2004.

Cappelletti M. Alternative dispute resolution within the framework of the world-wide access-to-justice movement. The Modern Law Review 1993;56(3):282-96. https://www.jstor.org/stable/1096668

Cappelletti M, Garth B. Access to justice and the welfare state: an introduction. In: Cappelletti M, miensa taustalla tai millaiset tekijät vaikeuttavat henkilökohtaista tilannetta. Taustalla voi olla esimerkiksi syrjintää iän, vähemmistöaseman tai sukupuolen perusteella, heikko taloudellinen asema tai yksinäisyyttä, mikä voi aiheuttaa osattomuuden kokemusta. Lisäksi selvitetään, miten tutkimukseen osallistuneet argumentoivat omaa tietouttaan ja ymmärrystään oikeuksista.

Useat tutkimukseen osallistuneet ovat ilmaisseet olevansa iloisia siitä, että ikääntyvän väestön kohtaamia oikeusongelmia kartoitetaan. Hankkeessa on mukana tutkijoina muun muassa vanhuusoikeuden, sosiaalityön ja yhteiskunnallisen oikeustutkimuksen osaajia. Kokonaisuudessaan kerätty tarina-aineisto on ainutlaatuinen ja tuottaa lähivuosina lukuisia tieteellisiä julkaisuja sekä kansantajuisia kirjoituksia. Lisäksi hankkeessa on tarkoitus toimittaa kokoomateos, jossa tutkijat valottavat ikääntyvien oikeudensaantimahdollisuuksia eri näkökulmista. Niin ikään on tärkeää käydä yhteiskunnallista keskustelua aiheesta.

\section{Kaijus Ervasti}

Itä-Suomen yliopisto

\section{Anna Mäki-Petäjä-Leinonen}

Itä-Suomen yliopisto

\section{Minni Teerikangas}

Helsingin yliopisto

ed. Access to justice and the welfare state. European University Institute, 1981:1-24.

Ervasti K. Oikeuden saamisen monet kasvot. Oikeus 2011;40(3):347-36. http://elektra.helsinki.fi/se/ 1/0023-7353/110/2/lakimieh.pdf

Ervasti K, Nylund A. Konfliktinratkaisu ja sovittelu. Helsinki: Edita, 2014.

Koskiaho B, Saarinen E, toim. Ihan pihalla? Vanhat ihmiset digitaalisen maailman myllerryksessä: neuvonnan, ohjauksen ja asioiden ajamisen järjestäminen. SOSTE Suomen sosiaali ja terveys ry, 2019. 